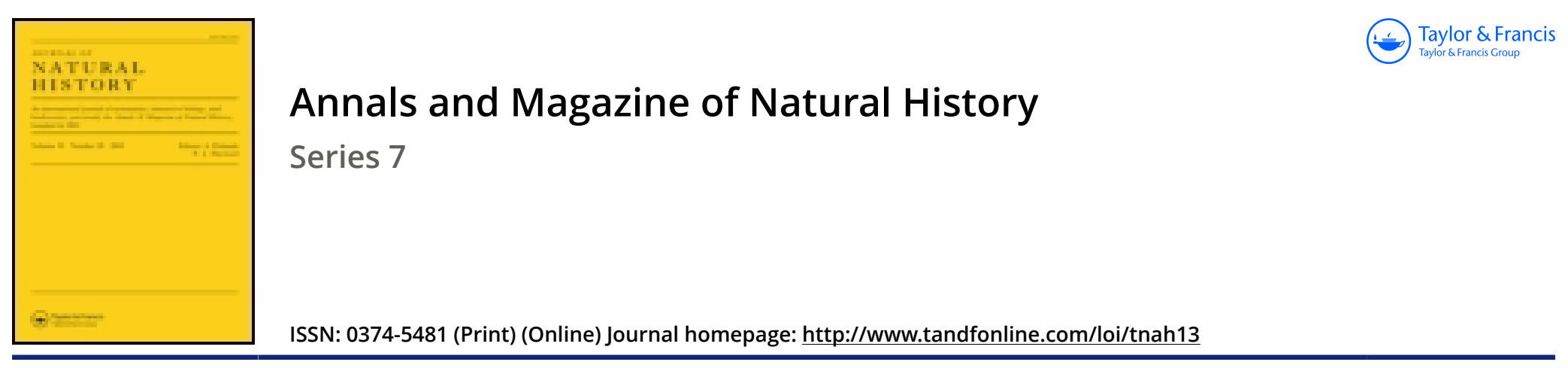

\title{
LX.-Description of a new West-African fish of the genus Alestes
}

\section{G.A. Boulenger F.R.S.}

To cite this article: G.A. Boulenger F.R.S. (1903) LX.-Description of a new West-African fish of the genus Alestes, Annals and Magazine of Natural History, 12:72, 594-595, DOI: 10.1080/00222930309487039

To link to this article: http://dx.doi.org/10.1080/00222930309487039

$$
\text { 曲 Published online: } 29 \text { Sep } 2009 .
$$

Submit your article to this journal $\lceil\pi$

Џ Article views: 4

Q View related articles 두 
594 Mr. G. A. Boulenger on a new West-African Fish.

form, from which it differs chiefly in the yellowish colour of the underparts.

$H$. Everetti is a small form of $H$. orientalis, but is markedly distinct, owing to the teeth-differences.

$H$. nepalensis much resembles $H$. orientalis, differing from it in being slightly larger. It is practically identical in size with $H$. personata.

The white tips to the hairs, although a conspicuous feature, are, owing to their variability, useless as a specific character. They are most noticeable in true personata, and, as a rule, entirely absent in nepalensis, orientalis, and Everetti; in the Chinese species, although present, they are of such a tint as to be hardly discernible.

\section{LX.-Description of a new West-African Fish of the Genus Alestes. By G. A. Boulenger, F.R.S.}

\section{Alestes brevis.}

Depth of body $2 \frac{3}{4}$ to 3 times in total length, length of head $3 \frac{3}{4}$ to $4 \frac{1}{4}$ times. Head $1 \frac{2}{3}$ to $1 \frac{3}{4}$ as long as broad, $1 \frac{1}{6}$ to $1 \frac{1}{5}$ as long as deep ; the distance between end of snout and occiput not or but slightly exceeding width of head; snout rounded, scarcely projecting beyond the lower jaw, 1 to $1 \frac{1}{2}$ as long as eye; eye lateral, visible from above and from below, its diameter 3 to $4 \frac{1}{3}$ times in length of head; adipose eyelid scarcely developed; interorbital width $\frac{1}{2}$ length of head; maxillary not reaching to below anterior border of eye; 18 or 20 teeth $\left(\frac{10-12}{8}\right)$ in the upper jaw; lower border of second suborbital as long as or longer than diameter of eye. Gill-rakers rather short and thin, 18 to 20 on lower part of anterior arch. Dorsal II 8, above middle of space between ventrals and anal, considerably nearer caudal than occiput; first branched ray longest, $\frac{3}{4}$ to $\frac{4}{5}$ length of head. Adipose fin short, twice or twice and a half as far from rayed dorsal as from caudal. Anal III 13-15, pointed in front, third simple ray longest, $\frac{2}{3}$ to $\frac{3}{4}$ length of head. Pectoral nearly as long as head, reaching or nearly reaching ventral. Latter shorter. Caudal deeply forked. Caudal peduncle not or but slightly longer than deep. Scales with numerous anastomosing 
canals, $21-23 \frac{4 \frac{1}{2}}{2 \frac{1}{2}}, 1$ or $1 \frac{1}{2}$ between lateral line and root of ventral. Uniform brownish above, silvery white below.

Total length 105 to 225 millim.

One specimen from Lagos (H.T. Ussher) and four from the Gold Coast (R.B. N. Walker). These specimens have been referred to $A$. macrolepidotus by Dr. Günther. Steindachner's A. macrolepidotus from Liberia (Notes Leyd. Mus. xvi. 1894, p. 63) probably belongs to the same species.

The four closely allied Alestes, characterized by very large scales and the very posterior position of the dorsal fin, may be distinguished as follows :-

A. The distance between the end of the snout and the occiput much greater than the width of the head; snout projecting considerably beyond the lower jaw in the adult.

Anal 15-17; lat. 1. 22-26; depth of body

$3 \frac{1}{3}$ to $4 \frac{1}{3}$ times in total length .........A. macrolepidotus, C. \& V.

B. The distance between the end of the snout and the occiput not or but little greater than the width of the head; snout projecting but slightly beyond the lower jaw.

Anal 13-14; lat. 1. 24-27; depth of body $3 \frac{1}{3}$

to $3 \frac{2}{3}$ times in total length............. A. grandisquamis, Blgr.

Anal 16-18; lat. 1. 21-23; depth of body $2 \frac{3}{4}$

to 3 times in total length ............ A. brevis, B!gr.

Anal 15-16; lat. I. 28-29; depth of body $3 \frac{1}{2}$

to 4 times in total length .............. A. Batesii, Blgr.

LXI.-Descriptions of Thirty-one Terrestrial and Fluviatile Mollusca from South Africa. By James Cosmo Metvill, M.A., F.L.S., and John Henry Ponsonby, F.Z.S.

[Plates XXXI. \& XXXII.]

AFTER an interval of more than two years * we are enabled to offer another contribution (the seventeenth) towards the elucidation of the non-marine Molluscan fauna of South Africa, in which are included descriptions of several species of Ennea and Trachycystis-T. scolopendra, perhaps, being the most remarkable Helicoid yet reported from this region. An Achatina, Buliminus, Planorbis, a most interesting Fauxulus, a Tropidophora, and a Chondrocyclus are, amongst

* Ann. \& Mag. Nat. Hist. ser. 7 (Oct. 1901), vol. viii. pp. 315 sqq. 